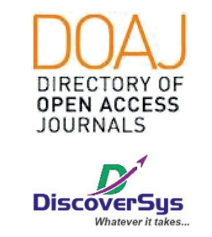

Published by DiscoverSys

\section{Gambaran dampak psikologis, sosial dan ekonomi pada ODHA di Yayasan Spirit Paramacitta Denpasar}

\author{
Nicholas Prathama Limalvin, ${ }^{*}$ Wayan Citra Wulan Sucipta Putri, ${ }^{2}$ \\ Komang Ayu Kartika Sari²
}

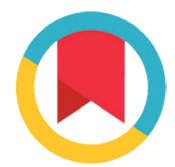

CrossMark

\title{
ABSTRACT
}

HIV or Human Immunodeficiency Virus is a type of virus that infects white blood cells and causes the decline of human immune. Physical problems are more visible in people living with HIV/AIDS (PLWHA). On the other hand, there are still psychological, social and economic problems that are still getting less attention from the community which also affect the lives of PLWHA. Aim: The purpose of this research is to describe the psychological, social and economic impact on PLWHA in Yayasan Paramacitta Spirit Denpasar as well as the form of hope and support that expected by PLWHA. Method: This study used qualitative method with 8 informants interviewed at Yayasan Spirit Paramacitta Denpasar and Poli NAPZA Sanglah Hospital Denpasar. Result: Some informants showed rejection or denial of his HIV status. Denial form that looks like depression until the desire to commit suicide.
Some informants said that the spiritual support and group of fellow PLWHA can reduce the denial. After some time PLWHA can change perception and start accepting their condition. Some informants are still withdrawing from the community and do not open their status to others for fear of stigma and discrimination from the public if they open their HIV status. In addition, if HIV status is not known, people living with HIV have not felt stigmatized and discriminated. Health workers complained of still providing stigma and discrimination on PLWHA. Family still plays an important role in providing financial support to PLWHA. An informant who lost their jobs is not because of their HIV status, but their physical condition. Conclusion: The form of support that expected by PLWHA is the recognition of the community and they are treated by the same as others.

Keywords: PLWHA, Psychological Impact, Social Impact, Economic Impact

Cite This Article: Limalvin, N.P., Putri, W.C.W.S., Sari, K.A.K. 2020. Gambaran dampak psikologis, sosial dan ekonomi pada ODHA di Yayasan Spirit Paramacitta Denpasar. Intisari Sains Medis 11(1): 81-91. D0I: 10.15562/ism.v11i1.208

\section{ABSTRAK}

HIV atau Human Immunodeficiency Virus adalah sejenis virus yang menyerang/menginfeksi sel darah putih dan menyebabkan turunnya kekebalan tubuh manusia. Di samping masalah fisik yang lebih terlihat pada ODHA (Orang dengan HIV/AIDS) masih ada masalah psikologis, sosial dan ekonomi yang masih kurang mendapat perhatian dari masyarakat yang tentunya juga mempengaruhi kehidupan dari ODHA. Tujuan: Tujuan dari penelitian ini adalah untuk mengetahui gambaran dampak psikologis, sosial dan ekonomi pada ODHA di Yayasan Spirit Paramacitta Denpasar serta bentuk harapan dan dukungan yang diharapkan ODHA dari masyarakat. Metode: Penelitian ini menggunakan metode kualitatif dengan jumlah informan 8 orang yang diwawancarai di Yayasan Spirit Paramacitta Denpasar dan Poli Napza RSUP Sanglah Denpasar. Hasil: Dalam penelitian ini didapatkan bahwa sebagian informan memunculkan penolakan atau denial akan status HIV-nya. Bentuk denial yang terlihat seperti depresi hingga adanya keinginan untuk bunuh diri. Sebagian informan mengatakan bahwa dukungan spiritual dan kelompok sesama ODHA dapat meringankan masa denial-nya. Setelah beberapa waktu ODHA bisa merubah persepsi dan mulai menerima kondisinya. Sebagian informan masih menarik diri dari masyarakat dan belum terbuka pada orang lain karena khawatir akan stigma dan diskriminasi dari masyarakat apabila mereka membuka status HIV-nya. Di samping itu, apabila status HIV tidak diketahui, ODHA belum merasakan stigma dan diskriminasi. Tenaga kesehatan dikeluhkan masih memberikan stigma dan diskriminasi pada ODHA. Keluarga masih berperan penting dalam memberi dukungan finansial kepada ODHA. Seorang informan kehilangan pekerjaan bukan karena status HIV-nya melainkan karena kondisi fisiknya. Simpulan: Bentuk dukungan yang diharapkan ODHA adalah pengakuan dari masyarakat dan diperlakukan sama seperti orang lain.

\footnotetext{
*Korespodensi:

Nicholas Prathama Limalvin, Program Studi Pendidikan Dokter, Fakultas Kedokteran Universitas Udayana

limprathama@gmail.com
}

Diterima: 06-04-2018

Disetujui: 16-06-2018

Diterbitkan: 03-03-2020
Kata kunci : ODHA, Dampak Psikologis, Dampak Sosial, Dampak Ekonomi

Cite Pasal Ini: Limalvin, N.P., Putri, W.C.W.S., Sari, K.A.K. 2020. Gambaran dampak psikologis, sosial dan ekonomi pada ODHA di Yayasan Spirit Paramacitta Denpasar. Intisari Sains Medis 11(1): 81-91. D0I: 10.15562/ism.v11i1.208

\section{PENDAHULUAN}

HIV atau Human Immunodeficiency Virus adalah sejenis virus yang menyerang dan menginfeksi sel darah putih dan menyebabkan turunnya kekebalan tubuh manusia. AIDS atau Acquired Immune Deficiency Syndrome adalah sekumpulan gejala yang timbul akibat infeksi dari virus HIV. Akibat 
turunnya kekebalan tubuh maka seseorang yang terinfeksi HIV sangat mudah terkena berbagai penyakit infeksi (infeksi oportunistik) yang sering berakibat fatal. ${ }^{1}$

Bali termasuk dalam sepuluh besar provinsi dengan jumlah kasus HIV/AIDS terbesar di Indonesia. Denpasar, Badung dan Buleleng adalah tiga nama kabupaten/kota dengan kasus HIV/ AIDS tertinggi di provinsi Bali. ${ }^{2}$ Menurut Dinas Kesehatan Provinsi Bali hingga tahun 2015 jumlah kasus HIV/AIDS terus meningkat. ${ }^{3}$

Masalah fisik merupakan hal yang lumrah pada orang dengan penurunan sistem kekebalan tubuh, banyak infeksi oportunistik yang muncul akibat dari infeksi HIV. Banyak studi telah melaporkan berbagai jenis infeksi oportunistik yang muncul pada pasien HIV/AIDS. Disamping masalah fisik yang lebih terlihat pada ODHA (Orang dengan HIV/AIDS) masih ada masalah psikologis, sosial dan ekonomi yang masih kurang mendapat perhatian dari masyarakat yang tentunya juga mempengaruhi kehidupan dari ODHA itu sendiri. ${ }^{4}$ Perbedaan perlakuan, stigma dan diskriminasi dari keluarga, masyarakat bahkan tenaga kesehatan membuat dampak sosial yang mendalam pada ODHA dan secara tidak langsung berdampak pada masalah psikologis serta ekonomi ODHA. ${ }^{5}$ Biaya pengobatan yang meningkat, produktivitas yang menurun hingga menyebabkan putus kerja menjadi sumber permasalahan ekonomi pada ODHA. ${ }^{6,7}$ Berbagai dampak ini menjadikan ODHA mengalami gangguan seperti depresi bahkan ada yang melakukan tindakan self-harmness hingga percobaan bunuh diri. ${ }^{8}$

Masalah psikologis, sosial dan ekonomi yang dialami ODHA membuat mereka menjadi populasi yang vulnerable. ODHA cenderung menarik diri dari masyarakat, merahasiakan masalahnya, interaksi dengan masyarakat pun akan berkurang, keterlibatan ODHA dalam organsisasi masyarakat lambat laun akan berkurang serta turunnya produktivitas kerja dari ODHA. Sesuai konsep paliatif, ODHA diharapkan dapat tetap beraktivitas sampai akhir hayatnya, maka dari itu perlu adanya dukungan masyarakat untuk mengatasi masalah psikologis, sosial dan ekonomi sehingga masyarakat perlu mengetahui dampak dan masalah yang dialami ODHA.

\section{METODE}

Penelitian ini merupakan peneitian kualitatif. Penelitian ini dilaksanakan di Yayasan Spirit Paramacitta Denpasar dan Poli Napza RSUP Sanglah Denpasar. Penelitian ini dilalukan dari bulan Maret 2017 hingga Juni 2017.
Pengambilan sampel menggunakan metode purposive sampling agar didapatkan variasi subyek penelitian. Metode pemilihan subyek ini berdasarkan kriteria yang relevan dengan tujuan penelitian. Pengambilan data menggunakan metode wawancara mendalam (indepth interview) untuk menggali peristiwa-peristiwa yang telah dialami oleh informan. ${ }^{9}$ Jumlah sampel yang diwawancarai sebanyak 8 informan yang bersedia untuk diwawancarai dan mengizinkan untuk digunakannya perekam suara sebagai bukti wawancara.

Variabel yang diteliti meliputi dampak psikologis, dampak sosial dan dampak ekonomi yang dialami oleh ODHA serta bentuk dukungan yang diharapkan oleh ODHA dari masyarakat.

Hasil wawancara akan diubah menjadi bentuk data transkrip wawancara untuk kemudian dikelompokkan berdasarkan variabel yang diteliti. Data transkrip yang telah dikelompokkan akan diambil beberapa subtema yang berkaitan dengan variabel yang diteliti.

\section{HASIL DAN PEMBAHASAN}

Pada 8 informan yang bersedia diwawancara untuk penelitian ini diperoleh kriteria informan seperti pada Tabel 1 berikut.

\section{Gambaran Dampak Psikologis}

Adanya Penolakan Setelah Mengetahui Status HIV-nya

Secara umum respon utama yang dimunculkan oleh ODHA saat mengetahui statusnya ada penolakan/denial. Bentuk denial yang muncul yang terlihat dari pernyataan informan adalah depresi, baik ringan sampai berat hingga adanya keinginan atau pemikiran untuk bunuh diri. Berikut kutipan yang diungkapkan oleh informan 06 dan 03.

Saya merasakan denial kurang lebih hampir satu tahun..... Stress-nya pasti, masih level standar, nggak sampai depresi. Saya sering nangis sendiri, tidak siap ketemu dengan orang banyak, masih standar. Tapi kalau melihat teman yang denial tingkat tinggi sampai ingin bunuh diri itu ada juga beberapa. (06)

Waduh, kalut. Jujur kalut, mas. Kayaknya hidup itu ndak berarti di dunia gitu lo..... Iya, sempat. Ada perasaan ke sana (ingin bunuh diri). Pokoknya, kayak ndak punya masa depan gitu lo, kayaknya. (03)

Depresi yang muncul pada ODHA hingga sampai melakukan tindakan bunuh diri memang pernah terjadi tidak hanya sebatas pada pemikiran 
Tabel 1 Identitas Informan yang Diwawancara

\begin{tabular}{lccll}
\hline Kode & Jenis Kelamin & Umur (Tahun) & Status Kawin & Pekerjaan \\
\hline 01 & $\mathrm{~L}$ & 24 & Belum Menikah & Tidak Bekerja \\
02 & $\mathrm{~L}$ & 38 & Menikah & Swasta \\
03 & $\mathrm{~L}$ & 37 & Menikah & Tidak Bekerja \\
04 & $\mathrm{~L}$ & 39 & Menikah & Tidak Bekerja \\
05 & $\mathrm{~L}($ Waria) & 38 & Belum Menikah & Pekerja Seks \\
06 & $\mathrm{P}$ & 41 & Cerai & Ibu Rumah Tangga (Pendamping Sebaya) \\
07 & $\mathrm{P}$ & 49 & Cerai & Ibu Rumah Tangga - Riwayat Pekerja Seks \\
& & & Cerai & Kendamping Sebaya) \\
08 & $\mathrm{P}$ & 43 & &
\end{tabular}

ODHA. Salah satu informan pernah mendengar bahwa kasus ODHA bunuh diri pernah terjadi di sebuah rumah sakit di Denpasar dan sempat dimuat dalam surat kabar. Berikut kutipan pernyataan informan 08 .

Ada kok kasusnya (ODHA bunuh diri). Di depan kasat mata kita merasa fine gitu. Artinya, dia bilang, "Saya terima" gitu..... Ternyata memang, secara personal orangnya introvert dan tidak terbuka pada siapapun. Jadi di depan kasat mata, "Oh ya nggak apa", tapi izin ke kamar mandi, ternyata bunuh diri kan, sampai ada di koran. (08)

Sebuah penelitian di China menyebutkan bahwa dampak psikologis yang paling terlihat pada ODHA meliputi rasa cemas dan depresi. Mulai dari pemikiran hingga percobaan bunuh diri muncul pada ODHA yang merasakan depresi yang berat. Satu dari tiga ODHA didapatkan memiliki pemikiran untuk bunuh diri atau bahkan telah melakukan percobaan bunuh diri. ${ }^{10}$

Jika dibandingkan dengan penelitian yang dilakukan di China tahun 2014, dampak psikologis yang terlihat pada ODHA setelah mengetahui status HIV-nya seperti depresi juga terlihat pada pernyataan informan. Pemikiran untuk bunuh diri juga dinyatakan beberapa informan setelah mengetahi status HIV-nya, namun dikatakan tidak sampai melakukan percobaan bunuh diri.

Denial yang muncul tidaklah sama pada setiap ODHA. Perbedaan ini terlihat pada ODHA yang mengatakan dirinya tidak beresiko dan ODHA yang memiliki perilaku beresiko. ODHA yang mengatakan dirinya tidak beresiko misalnya ibu rumah tangga memiliki kecenderungan mengalami denial yang lebih berat dan lebih lama apabila dibandingan dengan ODHA yang memang memiliki riwayat perilaku beresiko seperti mantan pemakai narkoba suntik dan pekerja seks. Seorang informan yang merupakan ibu rumah tangga menyatakan rasa tidak terima dan membandingkan dirinya dengan ODHA yang berperilaku beresiko. Berikut kutipan dari pernyataan informan 06, 07 dan 04.

Ibu lebih ke arah tidak terima ya, kenapa ibu-ibu rumah tangga (menangis). Nggak adil gitu rasanya, apalagi anak-anak. Sedangkan orang-orang diluar sana, lebih ke arah membandingkan gitu rasanya, orang-orang di luar sana, yang perilaku beresiko, ada beberapa dari mereka yang tidak terinfeksi. (06)

Ya stress, tapi stressnya sih nggak terlalu lama, itu karena juga kesalahan saya, karena mungkin juga teguran dari yang di atas. (07)

Ya perilaku udah gini ya biasa aja sih, ya mau gimana, terima lah. (04)

Dari pengalaman seorang informan selaku ketua yayasan yang sudah bertahun-tahun mendampingi ODHA, perbedaan riwayat perilaku dikatakan mempengaruhi berat tidaknya denial yang dialami oleh ODHA. ODHA yang menyatakan dirinya tidak beresiko akan memiliki masa denial yang lebih berat dibandingkan dengan mereka yang berperilaku beresiko. Berikut kutipan pernyataan informan 08.

Yang tidak beresiko, lebih tinggi ya denial-nya, artinya dia akan menyalahkan semua orang, dan bahkan menyalahkan yang di atas, "Kok tega ya", apalagi mereka yang rajin sembahyang, sholatnya rajin, cara kehinduannya, dia rajin ke pura gitu. Dia akan bernegosiasi dengan Tuhan, "Kenapa harus saya?", tidak terima dengan kenyataan. (08)

Sebuah review yang dilakukan di China menyebutkan bahwa ODHA yang HIV positif karena transfusi darah maupun karena pemakai narkoba suntik pernah mengalami depresi semasa 
hidupnya. Yang membedakan adalah saat dilakukan penelitian, presentase depresi yang menetap mereka yang HIV positif karena transfusi darah lebih banyak dibandingkan pada mereka yang pernah menggunakan narkoba suntik. ${ }^{11}$

Dari review yang dilakukan di China dapat disimpulkan bahwa ODHA yang HIV positif akibat transfusi darah cenderung memiliki denial berupa gangguan depresi lebih lama dan berat dibandingkan dengan mereka yang pernah menggunakan narkoba suntik. Ini juga dibuktikan pada penelitian ini bahwa ODHA yang mengaku dirinya tidak berperilaku beresiko masih merasakan denial yang menetap hingga saat ini, sedangkan mereka yang mempunya riwayat perilaku beresiko seperti pemakai narkoba suntik cenderung lebih menerima dan tidak terlalu memikirkan kondisi penyakitnya.

Upaya yang Dilakukan oleh ODHA untuk Keluar dari Masa Denial

Waktu yang diperlukan setiap ODHA untuk dapat menerima statusnya tidak semua sama, ada yang bisa menerima status dengan cepat karena menyadari memang perilakunya beresiko, ada pula ODHA yang memerlukan waktu lama untuk bisa menerima status HIV-nya, terlebih pada mereka yang mengaku perilakunya tidak beresiko seperti ibu rumah tangga. Beberapa dari informan memilih untuk menyendiri dan mencari spiritual support untuk mengatasi masa denial-nya. Berikut kutipan dari informan 06, 07 dan 01.

Mungkin berdoa, saya lebih banyak berdoa. (06)

Cara meringankan, saya mendekatakan diri pada Yang Maha Kuasa itu aja. (07)

Selain jalan-jalan sih, berdoa sih, lebih dekat dengan Tuhan. Ya pokoknya nggak usah dibawa stress. (01)

Sebuah penelitian yang dilakukan di Brazil menyatakan bahwa dukungan spiritual/agama dapat memberikan dampak positif pada mereka yang merasa tidak berdaya dan mengalami masa denial seperti ODHA. Disebutkan pula bahwa mereka yang mencari dukungan spiritual mendapatkan kenyamanan, kekuatan, serta rasa bersyukur untuk melawan penyakitnya. Dukungan spiritual juga dikaitkan membaiknya kondisi fisik ODHA seperti meningkatnya $\mathrm{CD} 4+$ pasien dan menurunnya viral load pada pasien. ${ }^{12}$

Seperti pada penelitian yang dilakukan di Brazil tahun 2017, mencari dukungan spiritual juga dilakukan oleh ODHA sesuai dengan kutipan pernyataan beberapa informan. Dukungan spiritual seperti berdoa membantu sebagian informan keluar dari masa denial-nya.

Selain dukungan spiritual, ada pula beberapa informan yang mencari jalan keluar dari masa denial-nya dengan mencari support dari teman sesama ODHA atau komunitas ODHA. Mereka berkumpul dengan sesama ODHA untuk mendapatkan rasa lega, rasa yang sama dan perasaan tidak sendiri setelah bercerita dengan ODHA yang lain. Berikut beberapa upaya yang dinyatakan oleh informan 03 dan 05 .

Kebetulan waktu itu, masih ikut methadon. Ke sini bisa nyari informasi, temen-temen bisa ngasih support, ada pertemuan-pertemuan saya ikutin tiap hari, kemana pun, saya ikutin tiap hari, akhirnya pikiran saya plong gitu lo, waktu itu. Akhirnya bukan saya sendiri aja yang gitu.

... sekarang sudah biasa, kan banyak teman juga yang sama, penyakitnya sama kayak saya. Kalau dulu kan masih rahasia. Sekarang saya ikut kelompok dampingan supaya ndak sendiri. (05)

Sebuah penelitian di Semarang tahun 2010 menyebutkan bahwa komunitas dukungan sesama ODHA dapat membantu ODHA agar tidak merasa sendiri dan dikucilkan dalam menghadapi masalah yang mereka hadapi. Komunitas ini juga bisa membantu ODHA untuk bertemu dengan orang lain dan memperoleh teman serta sebagai wadah untuk memperoleh sumberdaya ide dan informasi. Secara tidak langsung juga komunitas ini membantu ODHA menumbuhkan kembali rasa percaya dirinya dan rasa penerimaan dan pengertian terhadap kondisinya. ${ }^{13}$

Bertemu dan berkumpul dengan komunitas sesama ODHA menjadi stress reliever pada masing-masing ODHA, mereka dapat berbincang mengenai kondisinya, tanpa takut untuk mendapatkan perlakuan yang berbeda. Didapatkan pula pada hasil wawancara bahwa perilaku seperti ini masih menjadi cara yang paling sering dilakukan ODHA untuk mengatasi masalah psikologisnya, sesuai dengan hasil studi lain pada ODHA.

\section{Perubahan Persepsi Terkait Status HIV Setelah Melewati Masa Denial}

Setelah beberapa waktu, ODHA mulai keluar dari masa denial-nya dan mulai bisa menerima kondisinya. ODHA mulai berpikir lebih luas, tidak terfokus pada penyakitnya saja, mereka mulai membandingkan kondisi mereka dengan penyakit lain. Beberapa informan menyatakan bahwa mereka merasa beruntung menjadi ODHA apabila 
dibandingkan dengan orang yang mengidap penyakit lain misalnya kanker. Berikut peryataan dari informan 07 dan 02 .

Merasa beruntung sih (terkena HIV), merasa beruntung buat orang lain (menjadi pendamping sesama ODHA). Daripada kena kanker, harus dikemo. Kemarin sempat cerita dengan dokter katanya umurnya lebih panjang ODHA daripada orang dengan kanker atau diabetes. Ya agak merdeka dikit ya hahaha... (07)

Tapi kalau HIV itu saya termasuk bersyukurlah, masih bisa beraktivitas segala macem kan. Coba kaya orang stroke, kanker, tapi nggak bisa apa-apa. (02)

Tanggapan yang sama juga dinyatakan oleh ketua yayasan bahwa persepsi ODHA secara umum dapat berubah ke arah berpikir positif, berpikir dari sudut pandang yang lebih luas. ODHA menjadikan kondisinya sebagai titik balik untuk lebih mempertahankan kualitas hidupnya. Berikut kutipan dari informan 08 .

Itu kan sudut pandang mereka sudah luas ya..... Artinya kalau dia kebetulan berpikir positif jadinya kesitulah berpikirnya (membandingkan kondisi HIV-nya dengan penyakit lain). Artinya dia melihat dari sisi-sisi yang lain, misalnya secara spiritual umat Hindu, "Saya membayar karma saya". Mungkin juga ada yang berpikir, "Oh kalau saya nggak positif, mungkin saya berganti-ganti pasangan, berulang gitu perilaku saya". Jadi dia compare dengan orang lain, mungkin juga compare dengan orang cuci darah, "Oh saya tidak separah mereka yang menghabiskan uang banyak". Artinya kalau mereka berpikir dari sudut pandang yang lebih luas, dia akan berpikir, menjaga mutunya dengan lebih baik. (08)

Sebuah studi fenomenologi di Padang tahun 2015 menyebutkan bahwa seiring dengan berjalannya waktu dan adanya dukungan dari luar membuat ODHA dapat menerima kondisinya. Bentuk penerimaan akan kondisinya meliputi kepasrahan dan ketegaran. ODHA melihat segala sesuatu yang terjadi pada dirinya dapat dijadikan sebagai pelajaran hidup. Penerimaan akan kondisinya juga bergantung pada strategi koping yang dilakukan oleh tiap-tiap ODHA. ${ }^{4}$ Penelitian di Tanzania menyebutkan bahwa ODHA yang sudah menerima kondisinya, menganggap bahwa HIV/AIDS sama seperti penyakit pada umumnya. ${ }^{15}$

Perubahan persepsi setelah bisa menerima kondisinya tentunya berbeda, bergantung pada strategi koping yang dilakukan setiap ODHA untuk mengatasi masa denial-nya. Pada penelitian ini, informan menggunakan strategi koping dengan membandingkan kondisinya dengan penyakit lain seperti kanker atau stroke. Persepsi mereka menjadi lebih luas, tidak hanya memandang HIV hanya dari satu sisi. Beberapa informan menganggap bahwa kondisi ODHA yang masih bisa beraktivitas lebih baik dibandingkan dengan kondisi orang yang mengidap penyakit lain seperti kanker atau stroke.

Walaupun sudah melewati masa denial-nya, pikiran akan kondisinya mungkin tidak sepenuhnya hilang pada setiap ODHA meski telah mencari spiritual support dan bergabung dengan komunitas sesama ODHA untuk keluar dari masa denial-nya. Ada informan yang terkadang masih terpikir akan kondisinya, ada juga informan yang tidak mau terlalu stress memikirkan kondisinya. Berikut perbedaan pernyataan antara informan 06 dan informan 02.

Kadang-kadang sih (kepikiran), apalagi kalau melihat teman-teman ODHA yang pekerjaannya adalah ibu rumah tangga. Kadang-kadang, saya sampai denial tapi nggak sampai lama, saya harus sibuk, sehingga tidak memikirkan hal ini. Untuk apa toh saya pikirkan, toh juga tidak menyelesaikan masalah saya. (06)

Saya terima, karena saya yang berbuat saya terima, toh juga kalau saya pikirin saya juga nggak bakal sembuh, saya bawa cuek aja.... saya bawa rileks aja, kalau saya stress malah gampang penyakit, malah penyakit gampang nggerogoti kita, malah beban pikiran, malah ngedrop kita. (02)

Sebuah review di India tentang dampak depresi dan cemas pada pasien HIV menyebutkan bahwa rasa cemas dan depresi menjadi gangguan mental yang paling sering muncul pada ODHA. Kondisi ini muncul akibat banyaknya stress psikologis setelah ODHA mengetahui status HIV-nya. Stigma dan diskriminasi baik dari dalam diri ODHA maupun masyarakat juga bisa mencetuskan rasa cemas dan depresi pada ODHA. Ingatan akan mempunyai penyakit yang fatal juga mempengaruhi munculnya rasa cemas pada ODHA. ${ }^{16}$

Pada penelitian ini seorang informan mengatakan bahwa dirinya kadang masih kepikiran atau muncul kecemasan ketika melihat ibu rumah tangga lainnya yang terkena HIV. Kondisi tersebut mengingatkan kembali akan kondisi informan saat pertama kali mengetahui status HIV-nya. Sedangkan informan lain menyatakan sudah bisa menerima kondisinya dan tidak terlalu 
memikirkan penyakitnya, informan tersebut juga menyatakan bahwa stress akan memperburuk kondisinya.

\section{Gambaran Dampak Sosial}

\section{Sebagian ODHA Cenderung Menarik Diri dari} Masyarakat dan Belum Terbuka pada Orang Lain Setelah menjadi ODHA, tidak semua informan dapat kembali lagi masyarakat, kebanyakan dari mereka lebih memilih untuk bergaul sebatas komunitas sesama ODHA, yang dianggap lebih mengerti akan kondisi penyakitnya. Berikut kutipan pernyataan dari informan 03 dan 05 .

Di masyarakat sih, saya kurang bergaul jadinya. Kalau dulu sih sebelum tahu status, pergaulan saya di masyarakat bagus. Setelah tahu status kayak gini, bergaulnya ya ke sini, sesama ODHA, kalau sama yang lain mungkin ndak nyambung juga gitu. Hehehe... (03)

Enggak (terbuka sama teman lama), sama temen-temen waria aja, sama orang umum enggak saya terbuka. (05)

Selain bergabung dengan komunitas sesama ODHA, ada juga informan yang masih menarik diri dari masyarakat dan hanya berinteraksi sebatas melalui sosial media. Berikut pernyataan informan 01 .

Untuk sekarang saya masih menjauh (karena sakit). Saya juga sering pakai sosial media, saya posting foto lewat Instagram tapi tidak melihatkan saya sakit. (01)

Tidak semua informan menarik diri dari masyarakat, ada beberapa dari mereka yang mengungkapkan masih aktif pada kegiatan masyarakat misalnya kerja bakti, kumpul-kumpul banjar, namun dengan catatan orang lain tidak tahu akan status HIV dari ODHA tersebut. Berikut kutipan pernyataan dari informan 02, 06 dan 07.

Kerja bakti, biasa ikut-ikut aja. Tidak dijauhi. Mereka tahunya saya mantan pecandu sih. Tapi mereka tidak tahu status HIV. (02)

Masih, saya masih aktif (kegiatan banjar), dan pastinya saya tidak open status saya. (06)

Oh kalau kumpul-kumpul, ikut-ikut, saya sering ikut berjamaah di masjid. Setiap minggu saya belajar agama, belajar ngaji, karena waktu kecil dulu kurang belajar agama. Belajar ngaji, baca-baca Al-Quran, sebagai bekal nanti kalau saya dipanggil sama yang di atas. (07)
Sebuah penelitian di Semarang menyebutkan bahwa ODHA menarik diri dari lingkungan karena adanya rasa cemas akan sitgma dan diskriminasi. Stigma dan diskriminasi yang melekat pada masyrakat juga membuat ODHA semakin menarik diri dari lingkungan keluarga, lingkungan pertemanan dan lingkungan sekitarnya. ${ }^{17}$

Pada penelitian ini sebagaian dari informan memang tidak terlibat banyak dalam masyarakat karena adanya rasa cemas akan stigma dan diskriminasi akan kondisinya. Meskipun begitu, masih ada beberapa informan yang masih terlibat dalam kegiatan kerja bakti maupun kegiatan banjar dengan catatan mereka tidak membuka status HIV-nya.

Rasa Khawatir akan Stigma dan Diskriminasi menjadi Alasan diBalik Ketidakterbukaan ODHA akan Status HIV-nya

Kebanyakan dari ODHA hanya menceritakan kondisinya sebatas pada teman sesama ODHA, pasangan atau keluarga. Ada kepentingan lain dibalik ketidakterbukaan ODHA akan status HIV-nya misalkan untuk menjaga kondisi kesehatan baik fisik maupun psikisnya. Adanya stigma dan diskriminasi ditakutkan dapat mempengaruhi kondisi fisik dan psikis dari ODHA. Selain untuk menjaga kondisi fisik dan psikisnya, ODHA yang berkeluarga memilih untuk menutup status HIV-nya demi kepentingan anggota keluarga seperti anak dari ODHA tersebut. Berikut kutipan dari pernyataan informan 01, 02 dan 06.

Itu antara takut juga sih sebenarnya (takut bercerita kepada orang lain), orang kan tahu kalau sakit HIV itu kan penularannya melalui narkoba gitu jarum suntik, seks bebas atau apa. Kita ini stay di Bali, orang pasti pikirannya negatifgitu. (01)

Ya teman-teman yang ada di yayasan saja. Kalau yang di luar yayasan saya tidak buka status. Karena saya kasihan sama anak-anak saya. Tapi kalau saya nggak punya anak saya berani buka status saya. Karena saya pikir anak saya, saya takut anak saya dikucilkan, karena dicap jelek sekali di masyarakat. (02)

Padahal sebenarnya saya ingin membuka status anak saya (juga HIV positif) di sekolah, tapi saya takut anak saya mendapatkan perlakuan yang tidak manusiawi. (06)

Selain dari alasan fisik dan psikologis, ada juga informan yang mengungkapkan untuk menutupi statusnya demi kepentingan finansial seperti asuransi kesehatan. Berikut kutipan pernyataan informan 04. 
Nggak sih saya bilang, soalnya saya pake BPJS. Nanti ndak ditangani, rugi saya hahaha... Rugi saya punya BPJS nanti, kan ndak semua dokter juga bisa terima gitu. (04)

Sebuah penelitian di Tanzania menyebutkan bahwa ODHA merasa takut, merasa khawatir mendapatkan stigma dari pasangan bahkan dari keluarga ODHA sendiri. Disebutkan juga bahwa kekhawatiran ODHA juga sampai menyebabkan ODHA takut untuk mengakses ARV apabila bertemu dengan orang yang dikenalnya. ${ }^{15}$ Sedangkan penelitian di Iran menyebutkan bahwa mereka malu dan takut dikucilkan dari keluarga, diperlakukan berbeda di masyarakat. ${ }^{5}$

Berdasarkan penelitian yang dilakukan di Tanzania dan Iran, hasil yang didapatkan pada penelitian ini kurang lebih sama. Alasan dibalik ketidakterbukaan ODHA akan statusnya adalah rasa khawatir akan stigma dan diskriminasi kepada dirinya. Mereka takut mendaptkan perlakuan yang berbeda dari mayarakat. Seperti yang dikeluhkan oleh dua orang informan yaitu takut anaknya dijauhi hingga takut anaknya diperlakukan tidak manusiawi. Selain itu ada juga informan yang mengatakan bahwa takut asuransi kesehatan yang dimilikinya tidak bisa membiayai biaya kesehatannya nanti.

\section{Selama Status HIV tidak Diketahui, ODHA Belum} Merasakan Stigma dan Diskriminasi

Status HIV merupakan hal pribadi yang tidak gampang diungkapkan oleh ODHA kepada orang lain. Ini disebabkan karena masyarakat yang terbilang masih awan akan HIV/AIDS dan akan memunculkan respon negatif yang berlebihan yang berujung pada stigma dan diskriminasi pada ODHA itu sendiri. Namun, selama ODHA tidak membuka statusnya, stigma dan diskriminasi itu belum dirasakan oleh mereka. Berikut perbedaan kutipan pernyataan informan 02 dan 07 yang mengaku belum pernah memperoleh stigma dan diskriminasi serta pengalaman informan 03 saat membuka status HIV-nya.

Nggak pernah (dapat stigma dan diskriminasi). Karena nggak buka status. (02)

Karena belum membuka status, ya jadi belum pernah mengalami (stigma dan diskriminasi). (07)

Kan waktu saya dipukulin sama polisi, saya ngaku sama polisi itu, "Pak, status saya kena HIV". Akhirnya polisinya nggak berani mukul, dia mukulnya pake tongkat lagi mas waktu itu, nggak mau pake tangan, pake tongkat lagi, kan sakit waktu itu hahaha.... Setelah itu di dalam sel, ada kasus pembunuhan. Saya sempat nyabu sama orang kasus pembunuhannya. Saya kan berpikir kalau orang nyabu, air liur kan ndak mungkin menularkan. Ya, kalau ada luka, kan melalui darah. Kalau saya kan sudah tahu informasinya.... Dia mungkin, polisinya ngasih tau, sempet di situ dah saya digituin (diskriminasi). Dipisahin, kayak orang Bali, dicarikan guna-guna, kayak orang gila saya di situ mas, sampai ndak minum obat saya sempat, buang obat, takut saya waktu itu. (03)

Sebuah penelitian di Iran menyebutkan bahwa masyarakat juga memberikan perlakuan diskriminasi pada ODHA seperti menjaga jarak dari ODHA bahkan mengalihkan padangan ketika bertemu dengan ODHA. ODHA juga dilaporkan tidak bisa mendapatkan hak atas pendidikan, kesehatan hingga pekerjaan. ${ }^{5}$

Bentuk perlakuan masyarakat terhadap ODHA tentunya berbeda-beda, pada penelitian ini, beberapa informan menyatakan belum pernah mendapatkan perlakuan yang berbeda (stigma dan diskriminasi) dari masyarakat karena tidak membuka status HIV-nya. Berbeda dengan informan lainnya yang membuka status HIV-nya, informan tersebut mendapatkan pengucilan di dalam penjara hingga dipisahkan dari narapidana yang lain.

Mereka yang pernah membuka status HIV-nya pada orang lain terbukti mendapatkan perlakuan yang berbeda misalnya dari keluarga ODHA sendiri. Sempat ada informan yang bercerita bahwa dirinya harus dipindahkan ke desa setelah diketahui terkena HIV. Berikut kutipan pernyataan informan 05.

Ya, ini, takut tertular. Makanya aku diungsikan ke jauh ke kampung. Kan keluargaku di sini, punya rumah di Denpasar, tapi kampungku ada di Karangasem sana. Jadi aku diungsikan ke Karangasem. Berapa bulan tuh, satu tahun. Untuk pengobatan ARV sama TB..... Masih takut-takut dulu, masih pake selop tangan. Pake selop, pake masker dia (kakak yang merawat). (07)

Sebuah penelitian yang juga dilakukan pada Yayasan Spirit Paramacitta di tahun 2014 menyatakan bahwa stigma dan diskriminasi juga muncul dari keluarga ODHA, bentuknya seperti pengucilan kepada ODHA seperti membedakan tempat tinggal ODHA bahkan membuang perabotan yang telah digunakan oleh ODHA. ${ }^{18}$

Seperti hasil penelitian yang dilakukan pada tahun 2014, bentuk diskriminasi seperti pengucilan dari keluarga masih dirasakan oleh informan. 
Keluarga yang merawat masih memiliki rasa takut untuk kontak langsung dengan ODHA seperti menggunakan sarung tangan dan masker.

Stigma dan diskriminasi hingga saat ini masih terlihat jelas adalah pada mereka yang meninggal karena AIDS, jenazah ODHA mendapatkan perlakuan yang berbeda, seperti tidak dilakukannya prosesi pemandian jenazah. Salah seorang informan pernah mendengar kabar mengenai pembedaan perlakuan pada jenazah ODHA, namun suami informan yang meninggal karena AIDS tidak mendapatkan perlakuan yang berebeda karena status HIV suaminya dirahasiakan. Berikut kutipan pernyataan dari informan 06 .

Saya takutnya nanti terjadi diskriminasi saat proses pemandian (suami). Jangankan beberapa tahun ini, sampai beberapa saat ini saja saya masih sempat dengar pembedaan proses pemandian jenazah. (06)

Berita akan pembedaan perlakuan pada jenazah juga pernah didengar oleh ketua yayasan. Dikatakan oleh informan tersebut bahwa kejadian pembedaan dalam memperlakukan jenazah memang masih ada dan masih terjadi. Berikut kutipan pernyataan informan 08 .

Dan sekarang mendapatkan stigma sih jenazah ODHA. Misalnya orang yang meninggal karena AIDS, biasanya keluarganya kaget, kadang cuma ditirtain aja, lalu dibawa ke tempat kremasi. (08)

Bentuk diskriminasi lainnya masih terlihat pada ODHA yang telah meninggal. Kasus ini pernah terjadi di Gianyar. Ketika ada warga yang meninggal akibat terinfeksi HIV, warga yang lainnya tidak mau memandikan jenazah tersebut kerena takut tertular HIV. ${ }^{18}$

Dari hasil penelitian Diatmi dan Diah tahun 2014 didapatkan hasil yang sama dari pernyataan-pernyataan yang diungkapkan oleh informan bahwa perbedaan dalam memperlakuan jenazah masih terdengar. Namun, pembedaan dalam memperlakukan jenazah hanya sebatas rasa khawatir dan tidak dialami oleh suami informan 06 karena status HIV-nya masih dirahasiakan.

TenagaKesehatanMasihMemberikanStigmadan Diskriminasi pada ODHA

Dengan berkembangnya ilmu pengetahuan, tenaga kesehatan mulai bisa mengurangi stigma dan diskriminasi pada ODHA. Para tenaga kesehatan sudah mengerti bagaimana cara memperlalukan ODHA. Namun tetap saja stigma dan diskriminasi tetap dialami oleh ODHA. Seorang informan sempat mengatakan bahwa dirinya tidak bisa memperoleh layanan kesehatan akibat status HIV-nya. Berikut perbedaan perlakuan yang didapatkan oleh informan 01 dan 07 saat berobat ke rumah sakit.

.... waktu di Sulawesi nih, aku kan pengen sempat mau operasi, di rumah sakit ini saya bilang mau operasi lalu mereka terima, setelah saya bilang pengidap HIV, mereka bilang "Maaf mas, buat di rumah sakit ini nggak bisa nerima pengidap HIV, karena peralatannya nggak lengkap..... Sempat juga dirujuk ke rumah sakit lain, tapi dokter di sana nggak ngelihat, nggak nyentuh.... (01)

Nggak, nggak ada (stigma dan diskriminasi dari tenaga kesehatan). Kemarin mau operasi mata, aku bilang ke dokternya, aku terbuka duluan, "dok, aku sebelumnya minta maaf aku ODHA, dokter mau operasi mata saya?" Oh nggak apa, kata dokternya. (07)

Berdasarkan pengalaman ketua yayasan, tenaga kesehatan yang pada mulanya memunculkan stigma dan diskriminasi pada ODHA dikarenakan mereka yang terlibat kontak langsun dengan ODHA. Hingga saat ini, stigma dan diskriminasi dari tenaga kesehatan masih tetap terjadi, baik melalui perkataan, perbuatan maupun bahasa tubuh yang bisa dirasakan oleh ODHA. Dikatakan pula oleh ketua yayasan bahwa stigma dan diskriminasi dari tenaga kesehatan tidaklah sebanyak dulu. Berikut kutipan dari pernyataan informan 08 .

Itu dulu ya (stigma dan diskriminasi), tahun 90-an, bahkan dokter yang menimbulkan stigma itu, rumah sakit, yang menjadi contoh. Mereka yang dipandang sebagai contoh, takut, mengeluarkan reaksi yang berlebihan seperti menggunakan pakaian seperti astronot. Kenapa? Karena mereka yang kontak langsung dengan ODHA. Bekas darah gitu misalnya di beri tulisan bekas ODHA. Tapi itu dulu tahun 90an dan 2000an. Tapi sekarang kita sudah advokasi kemana-mana, dan layanan kesehatan sudah menerima. Dari layanan pun sudah tidak ada stigma dan diskriminasi, bahkan puskesmas juga tidak ada. (08)

Sebuah studi di Kerman, Iran, tenaga kesehatan juga dilaporkan masih memberikan stigma dan diskriminasi pada ODHA. Berbagai macam perlakuan dialami oleh ODHA dari tenaga kesehatan seperti tidak mau melakukan pemeriksaan, pelayanan yang tidak optimal, memberikan jarak kepada ODHA serta memberikan pernyataan yang menghakimi. Menurut pengalaman seorang 
pasien, perawat di sebuah rumah sakit di sana tidak mau melepaskan kateter yang terpasang pasien tersebut, bahkan menyuruh pasien tersebut melepas kateternya sendiri. ${ }^{5}$

Jika dibandingkan hasil penelitian dengan studi yang dilakukan di Kerman, Iran memang benar stigma dari dan diskriminasi dari tenaga kesehatan masih terjadi di Indonesia. Masih terdapat layanan kesehatan yang tidak mau memberikan pelayanan kepada mereka yang positif HIV. Stigma dan diskriminasi dari tenaga kesehatan dirasakan oleh informan pada saat berada di Sulawesi. Informan yang bersangkutan melaporkan bahwa dokter yang bertugas tidak mau melihat dan menyentuh informan. Sedangkan untuk pengalaman informan lain didapatkan dokter sudah mau menerima ODHA dan memperlakukan ODHA selayaknya pasien pada umumnya. Dari perbedaan ini dapat ditarik kesimpulan bahwa tidak semua tenaga kesehatan di Indonesia memperlakukan ODHA sama seperti pasien pada umumnya.

\section{GAMBARAN DAMPAK EKONOMI}

Status ekonomi ODHA secara umum memang menurun, namun tidak semua ODHA mengalami penurunan status ekonomi apabila mereka banyak mendapatkan dukungan finansial baik dari keluarga, dinas sosial maupun lembaga lainnya. Dukungan finansial yang diberikan keluarga masih berperan penting dalam membantu kondisi ekonomi ODHA seperti bantuan dana untuk kebutuhan sehari-hari. Berikut kutipan dari pernyataan informan 01 dan 03.

Aku juga terbuka sama tanteku satu, kayaknya dia bisa bantu sama saya. Saya cerita tapi minta tolong agar tidak diceritakan ke keluarga yang lain. Dia sampai kaget, dan bertanya detail dari $A$ sampai Z. Dan akhirnya mulai membantu dana. Itu dah peran dari keluarga, kalau saya nggak cerita ke keluarga siapa yang mau bantu. (01)

.... kalau nggak cukup ya saya ngutang dulu gitu, kalau saya sih masih minta saya ibu saya. Saya nggak pernah minta sama istri saya. Tapi saya minta sama ibu saya. Dikasi, paling sepuluh ribu, dua puluh ribu. (03)

ODHA yang masih dekat dengan keluarganya tidak mengalami penurunan kondisi ekonomi yang begitu derastis karena keluarga masih memberi dukungan finansial kepada ODHA. Berbeda dengan kelompok masyarakat yang berprofesi sebagai pekerja seks seperti waria. Dampak finansial akan sangat terlihat pada mereka yang berprofesi demikian. Hal ini juga dikatakan oleh ketua yayasan yang terlibat dalam mendampingi kelompok waria yang HIV positif. Berikut kutipan dari informan 05 dan 08.

Kadang cukup, kadang enggak, tapi kalau untuk makan ya ada aja. (05)

Kalau seperti kita, yang dekat dengan keluarga masih akan ada yang membantu. Lain cerita kelompok kunci seperti waria, itu yang kelihatan sekali dari segi ekonomi langsung menurun. (08)

Salah satu fungsi keluarga adalah fungsi ekonomi. Peran keluarga sangatlah penting untuk membantu ODHA untuk mendapatkan dukungan material seperti dana. Keluarga membatu dana bagi ODHA untuk memperoleh obat ARV dan untuk kehidupan keseharian ODHA..$^{19,20}$

Penurunan kondisi ekonomi pasti dialami oleh ODHA, karena mereka harus menyisihkan penghasilan mereka untuk biaya kesehatan yang tentunya meningkat misalnya untuk pemeriksaan rutin dan obat ARV. Dari sebuah hasil studi pada tahun 2016 tentang peran keluarga terhadap kehidupan ODHA didapatkan bahwa keluarga sangat berperan penting dalam membantu memulihkan kondisi ekonomi ODHA. Pada penelitian ini didapatkan hasil bahwa keluarga masih berperan penting dalam membantu ODHA dari segi finansial.

Kondisi ekonomi ODHA dipengaruhi oleh produktivitas yang menurun. Produktivitas ODHA menurun karena kondisi fisik mereka menjadi cepat lelah, mudah sakit sehingga sering tidak masuk kerja bahkan sampai berhenti bekerja. Mereka yang putus kerja atau kehilangan pekerjaan karena statusnya masih jarang ditemukan. Menurunnya kondisi fisik ODHA yang mempengaruhi status pekerjaan karena tidak cukup produktif untuk melaksanakan pekerjaannya. Hal yang sama juga diungkapkan oleh ketua yayasan yang sudah lama mendampingi ODHA bahwa jarang ditemukan bahwa ODHA berhenti karena status HIV-nya melainkan mundur karena kondisi fisiknya. Berikut pernyataan dari informan 01 dan 08.

Iya (mundur dari pekerjaan),.... waktu musim hujan juga, waktu itu kerja di pinggir pantai sih, Beach Club gitu. Aku kira sakit dapet dari sana, batuk pilek, teman-teman juga ada yang batuk pilek. Tapi gejala yang paling kelihatan sih mencret, pokoknya perutku itu kayak diputer, dikeluarin, nggak ada nafsu makan, udah gitu aja. (01) 
Kalau berhenti kerja karena sakit iya. Kalau karena dia memberitahukan statusnya, jarang sih, bisa dihitung. Tapi kalau yang kerja-kerja biasa di sini tidak terlalu penting (memberitahu status HIV-nya). (08)

Sebuah studi pada tahun 2014 menyebutkan ODHA sering jatuh sakit. Mereka bisa demam yang tak kunjung hilang hingga mereka harus berbaring lama di tempat tidur. Dengan ini produktivitas ODHA tentu akan turun, mereka tidak bekerja dan tidak bisa membiayai hidupnya. ${ }^{18}$

Dari hasil penelitian ini didapatkan bahwa seorang informan berhenti dari pekerjaannya karena kondisi fisiknya yang menurun. Apabila dibandingkan dengan penelitian di tahun 2014, didapatkan hasil yang sama, karena kebanyakan dari ODHA berhenti kerja karena kondisi fisiknya yang menurun, bukan karena status HIV-nya.

\section{Harapan dan Support yang Diinginkan ODHA}

Pada saat wawancara, para informan juga mengutarakan harapan dan bentuk dukungan seperti apa yang mereka perlukan untuk membantu mengatasi masalah psikologis, sosial dan ekonomi yang mereka alami. Salah satu bentuk dukungan yang paling penting yang dinyatakan informan adalah pengakuan, pengakuan akan kondisi ODHA. Seorang informan juga berharap bahwa ODHA diberlakukan sama seperti orang pada umumnya. Masyarakat yang secara umum masih awam lebih diedukasi mengenai HIV/AIDS agar bisa menekan stigma dan diskriminasi pada ODHA. Berikut kutipan pernyataan informan 06, 01 dan 03.

Paling bentuk pengakuan saja, karena orang dengan HIV itu cap buruknya susah sekali hilang. Mereka beranggapan bahwa orang HIV yang positif itu adalah orang-orang dengan perilaku seks menyimpang, yang tidak benar. Padahal sebenarnya, bagaimana dengan kami, ibu-ibu rumah tangga, anak-anak, apakah merka pantas mendapatkan perlakuan seperti itu. Pengakuan yang kami inginkan.... kalau material, apabila masyarakat bisa merangkul kami, segala macam pekerajaan bisa mereka berikan. Banyak juga teman-teman yang diketahui status HIV positifnya, mereka harus di-cut dari pekerjaannya. Itulah sebabnya pengakuan, yang diperlukan. Agar di setiap instansi kami bisa bekerja, tanpa adanya pembedaan. (06)

Masyarakat sih lebih menerima sih, ODHA itu, lebih banyak ke penyuluhan ke sekolah-sekolah. (01)
Kalau dari masyarakat sih, biar orang HIV bisa diterima kayak orang penyakit-penyakit lainnya gitu lo. Jangan di stigma, didiskriminasi. (03)

Hingga saat ini keluarga sangat berperan penting dalam memberikan dukungan pada ODHA baik fisik, psikis, sosial maupun ekonomi. Ada informan yang hingga saat ini belum mengungkapkan statusnya kepada anaknya, namun informan tersebut berharap agar suatu saat apabila sakit, anaknya mau menerima dan merawat dirinya. Secara tidak langsung diharapkan bahwa semua keluarga ODHA ikut terlibat dalam memberikan support pada ODHA, agar tidak menghadapi masalahnya sendirian. Berikut kutipan dari informan 07.

Kalau dari anakku sendiri, kalau misalnya aku terbuka, suatu saat kalau misalnya aku sakit, biar dia tahu, biar dia yang merawat aku. (07)

Selain pengakuan dari masyarakat, dukungan secara finansial juga diperlukan oleh ODHA. Beberapa informan lebih memfokuskan pada dukungan finansial secara tidak langsung seperti menggratiskan akses obat ARV maupun biaya sekolah untuk anak-anak agar tidak memberatkan ODHA yang berstatus ekonomi menengah ke bawah. Berikut kutipan pernyataan informan 02 dan 03.

Ya dukungan moral, (dan) bantuan biaya sekolah untuk anak-anak biar ndak sampai putus sekolah. (02)

Dan dari pihak pemerintah, sudah baik sih, tapi ya sedikitnya masih ada kekurangan pastinya. Obatnya biar bisa digratiskan, biar nggak bayar sama sekali hahaha... (03)

\section{SIMPULAN}

Gambaran dampak psikologis yang dialami oleh ODHA secara umum adalah denial atau tidak terima terhadap kondisinya seperti depresi hingga keinginan untuk bunuh diri. Mereka yang mengaku perilakunya tidak beresiko cenderung mempunyai masa denial yang lebih lama. Sebagian informan mengatasi masa denial-nya dengan mencari dukungan spiritual misalnya berdoa atau bergabung dengan kelompok sesama ODHA. Setelah beberapa waktu, ODHA dapat merubah persepsi akan HIV dan mulai bisa menerima kondisinya.

Gambaran dampak sosial yang dialami ODHA tidak sama setiap informan, namun selama mereka tidak membuka status mereka, stigma dan diskriminasi pada mereka tidak dirasakan. Bentuk 
diskriminasi dari keluarga, polisi, dan tenaga kesehatan masih sempat dirasakan oleh beberapa informan. ODHA cenderung menutup statusnya pada masyarakat karena rasa khawatir mendapatkan stigma dan diskriminasi. Pembedaan perlakuan pada jenazah ODHA juga dikatakan masih terjadi.

Gambaran dampak ekonomi yang dialami oleh ODHA secara umum status ekonomi ODHA menurun, dikarenakan produktivitas yang menurun. Meskipun begitu, kondisi ekonomi ODHA tidak terlalu menurun apabila mereka masih mendapatkan bantuan dari keluarga maupun pihak lainnya. Status HIV memang menghalangi mereka untuk memperoleh pekerjaan, namun selama status HIV tidak diketahui, kesempatan kerja ODHA masih tetap sama.

Bentuk dukungan yang diharapkan oleh ODHA adalah pengakuan akan kondisi ODHA, tidak lagi ada stigma dan diskriminasi pada ODHA, masyarakat lebih diedukasi mengenai informasi HIV/AIDS serta biaya untuk pengambilan ARV ditiadakan.

\section{DAFTAR PUSTAKA}

1. Kementrian Kesehatan Republik Indonesia. Situasi dan Analisis HIV AIDS; 2014

2. Rini T, Lestari P. Kebijakan Pengendalian HIV / AIDS di Denpasar. J Kesehat Masy. 2013;8(1):45-8.

3. Dinas Kesehatan Provinsi Bali. Profil Kesehatan Provinsi Bali Tahun 2015. Denpasar; 2016.

4. Dejman M, Ardakani HM, Malekafzali B, Moradi G, Gouya MM, Shushtari ZJ, et al. Psychological, Social, and Familial Problems of People Living with HIV/AIDS in Iran: A Qualitative Study. Int J Prev Med. 2015;6(126):1-9.

5. Karamouzian M, Akbari M, Haghdoost A-A, Setayesh H, Zolala F. "I Am Dead to Them": HIV-related Stigma Experienced by People Living With HIV in Kerman, Iran. J Assoc Nurses AIDS Care. 2014;1-11.

6. Basavaraj KH, Navya MA, Rashmi R. Quality of life in HIV / AIDS. Indian J Sex Transm Dis AIDS. 2010;31(2):75-80.

7. Pardita DPY. Analisis Dampak Sosial, Ekonomi, dan Psikologis Penderita HIV AIDS di Kota Denpasar. Universitas Udayana; 2014.
8. Rosenfeld D, Anderson J, Ridge D, Asboe D, Catalan J, Collins S, et al. Social Support, Mental Health, and Quality of Life Among Older People Living with HIV. 2015.

9. Raco JR. Langkah-Langkah Penelitian Metode Kualitatif. In: L A, editor. Metode Peneltian Kualitatif. Jakarta: Grasindo; 2010. p. 98-132.

10. Sun W, Wu M, Qu P, Lu C, Wang L. Psychological well-being of people living with HIV/AIDS under the new epidemic characteristics in China and the risk factors: A population-based study. Int J Infect Dis. 2014;28:147-52.

11. Niu L, Luo D, Liu Y, Silenzio VMB, Xiao S. The Mental Health of People Living with HIV in China, 1998-2014: A Systematic Review. PLoS One. 2016;11(4):1-18.

12. Pinho CM, Dâmaso BFR, Gomes ET, Trajano M de FC, Andrade MS, Valença MP. Religious and spiritual coping in people living with HIV/Aids. Rev Bras Enferm. 2017;70(2):392-9.

13. Kamila N. AS. Persepsi Orang dengan HIV dan AIDS terhadap Peran Kelompok Dukungan Sebaya. J Kesehat Masy. 2010;6(1):36-43.

14. Gusti R, Farlina M. Studi Fenomenologi Pengalaman Orang Hiv/Aids (Odha) Dalam Mendapatkan Dukungan Keluarga Di Yayasan Lantera. J Ners. 2015;11(1):22-31.

15. Mhode M, Nyamhanga T. Experiences and impact of stigma and discrimination among people on antiretroviral therapy in Dar es Salaam: A qualitative perspective. AIDS Res Treat. 2016;2016:1-11.

16. Chaudhury S, Bakhla AK, Saini R. Prevalence, Impact, and Management of Depression and Anxiety in Patients with HIV: A Review. Neurobehav HIV Med. 2016;7(May):15-30.

17. Arriza BK, Dewi EK, Veronika D, Kaloeti S. Memahami Rekonstruksi Kebahagiaan pada Orang dengan HIV/AIDS (ODHA). J Psikol Undip. 2011;10(2):153-62.

18. Diatmi K, Diah IG a. Hubungan Antara Dukungan Sosial dengan Kualitas Hidup pada Orang Dengan HIV dan AIDS ( ODHA ) Di Yayasan Spirit Paramacitta. J Psikol Udayana. 2014;1(2):353-62.

19. Rahakbauw N. Dukungan Keluarga Terhadap Kelangsungan Hidup ODHA (Orang dengan HIV/AIDS). INSANI. 2016;3(2):64-82.

20. Muliawan, P., Sawitri, A. 2016. Prevalence of HIV Infection Among Tuberculosis Patients in Bali, Indonesia. Bali Medical Journal 5(1): 65-70. DOI: 10.15562/bmj.v5i1.272

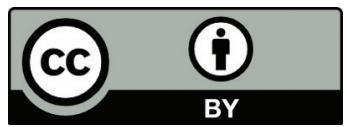

This work is licensed under a Creative Commons Attribution 